\title{
The Meaning and Functions of the Concept of
}

\section{Yuanfen 缘分 in Contemporary China:}

\section{A Qualitative Study with Students from East China Normal University}

\author{
Isabel Heger
}

\begin{abstract}
Yuánfèn can best be defined as a kind of subjectively perceived chance that brings people or people and events together. Being able to provide explanations in a positive way, Yuanfen has always functioned as an attribution, the psychological process of seeking reasons for particular events. The aim of this study was to investigate the meaning and functions of Yuanfen for university students in the PRC, which should give an insight into the meaning of the concept in a specific social context within contemporary China. The results were obtained through semi-structured interviews with 19 students from East China Normal University in Shanghai that were conducted in 2012. The data was analysed through qualitative content analysis. The findings show that if Yuanfen has individual meaning for Chinese students, attributing life events to the concept has very positive functions, leading to a positive perception of and a positive attitude towards different relationships, events, and situations. Yuanfen can therefore play a very positive role in Chinese student life, not only for the individual, but also for the social environment of university education in which the students are confronted with a range of structural and interpersonal challenges.
\end{abstract}

Keywords: Yuanfen 缘分, cultural psychology, attribution, Chinese students

Heger, Isabel. "The Meaning and Functions of the Concept of Yuanfen 缘分 in Contemporary China: A Qualitative Study with Students from East China Normal University." In Vienna Journal of East Asian Studies, Volume 7, eds. Rudiger Frank, Ina Hein, Lukas Pokorny, and Agnes Schick-Chen. Vienna: Praesens Verlag, 2015, pp. 129-163. https://doi.org/10.2478/vjeas-2015-0005 


\section{Introduction: Aims of the Study and Current State of Research}

Yuánfèn 缘分 is an indigenous Chinese concept with manifold and complex meanings that have evolved over the course of history. It can best be defined as a kind of subjectively perceived chance that brings people or people and events together. Because no Western term can capture the essence of this concept, Yuanfen will be used as a technical term throughout this paper.

Yuanfen plays an important role in Chinese culture. Being able to provide explanations for different relationships, events, and situations, it has always functioned as an attribution, the psychological process of seeking reasons which influences individual perception and actions. In line with the basic assumption of cultural psychology that culture shapes all of our thinking and acting, studying the meaning of Yuanfen for Chinese people can contribute to our understanding of some interesting psychological and social phenomena in contemporary China.

However, relatively little research has been done on Yuanfen so far, probably for two reasons: Firstly, in the Chinese cultural sphere, the concept is taken for granted and thus seldomly investigated. Secondly, Western sinologists are often not fully aware of the significance of the concept. To the author's best knowledge, less than 30 scientific papers, ${ }^{1}$ most of them in Chinese, have focused on Yuanfen as a main research subject in the more than 30 years since 1982, when the first comprehensive scientific study on the concept was published by the Taiwanese cultural and social psychologist Yáng Kuó-shū 杨国枢. ${ }^{2}$

Previous studies have laid solid foundations in respect of the concept per se, its psychological functions, and its importance in interpersonal relationships. But from a sinological perspective there are still several research gaps to be closed. One fact in particular served as the starting point for the present study, namely that even though Chinese university students have been the target group of studies on Yuanfen (for example, Yáng 1988; Chang and Holt 1991; Liú 2010) before, no study has yet explored the phenomenon against the backdrop of the specific social context of Chinese university life.

Based on this observation, the aim of the present research is to investigate the meaning and the functions of Yuanfen for university students in the People's Republic of China (PRC). It is hypothesised that 1) attributing relationships and events to Yuanfen has positive functions for Chinese students, that 2) the special circum-

Authors' Note: This paper was partly funded by a short-term grant for research abroad (KWA) by the University of Vienna in 2012.

1 Scientific papers are not to be confused with essays and personal accounts on Yuanfen that do exist in great number in China, and which can often even be found on academic platforms.

2 The initial study by Yáng Kuó-shū (1982b) was republished twice, once in Chinese (1988) and once in English with David Y. F. Ho (1988). In what follows, this paper will mostly refer to the Chinese publication from 1988. It will only refer to the English publication if it provides additional content. 
stances of Chinese student life provide fertile ground for Yuanfen-attributions and that 3) the positive functions of Yuanfen for the individual have an impact on Chinese society as a whole, contributing to the maintenance of stability and harmony. These hypotheses will be critically examined in the course of this paper, by analysing qualitative interviews with 19 students from East China Normal University (ECNU) (Huádōng Shīfàn Dàxué 华东师范大学) that were conducted during a period of six weeks in the autumn of 2012.

\section{The Semantic Evolution of Yuanfen}

The meaning of Yuanfen as we know it is the result of a complex semantic evolution, ${ }^{3}$ starting with the character yuán 缘. Originally pronounced yuàn, it described the seam or embroidered hem in clothing, which is still the semantic root for the translation of yuán as 'edge or border' (Luó 1992: 956). During the Han Dynasty (207 BC-220 AD), however, a derivative meaning for the character came into being in the form of yinyuán 因缘, 'foundation or basis' (Bái 2004).

When Buddhism first entered China during the Han Dynasty, it so happened that the word yinyuán was used to translate a key element of the Buddhist doctrine of the 'Twelve Nidanas' (shí 'èr yīnyuán' 十二因缘). ${ }^{4}$ Historians assume that yīnyuán was chosen because of its semantic similarity to the original term, making it easy to repurpose the meaning of the two characters in order to convey the essence of the Buddhist doctrine. In its new meaning, yin 因 became the primary cause, while yuán became the secondary or circumstantial cause crucial for the production of a certain effect (Bái 2004). In other words: 'The direct cause is the seed, and yuan is the soil, rain, and the sunshine' (Soothill and Hodous 1968: 440 cited in Chang and Holt 1991: 35).

Initially, Buddhist concepts were spread in their original form. However, following the blossoming of Buddhism in China from the Táng-Dynasty (618-907) onwards, they eventually became indigenous Chinese concepts (Bái 2004). This sinicisation of Buddhist concepts is the result of a process of secularisation and utilisation - even though common people did not understand complex Buddhist concepts, they integrated them into their world view and daily life where they could serve a certain purpose (Yáng 1988 and Jīng 2005).

Yinyuán asserted the prevailing view in Chinese tradition that things were predetermined by fate. What is more, the new concept of yuán was perceived as the crucial factor determining when and how a predetermined fate would impact upon one's life, which the individual could not influence and had to accept powerlessly

3 The complete semantic evolution of the character is very well outlined in the 'Big Dictionary of Chinese' (Hànyǔ dà cídiăn 汉语大辞典) (Luó 1992: 956ff).

4 For more information on the doctrine, see Bái Hóngzhōng 白宏钟 (2004). 
(Bái 2004). In this fatalistic way, yuán and later Yuanfen ${ }^{5}$ were anchored in the common mindset of people in traditional China (Bái 2004).

Even today, the traditional roots of the concept still shine through in various expressions. Through content analysis of all phrases containing yuán or Yuanfen found in an online dictionary compiled by the Education Bureau of Taiwan, Cheng and Yau (2006) identified three nuances in the conception of Yuanfen: It either appears as a precious chance of encounter given the small probability to meet one out of a myriad of persons, as a secondary or auxiliary cause next to a primary cause, or as the effect of a cause.

\section{Changing Conceptions of Yuanfen Over the Course of Time}

As a cultural concept, Yuanfen is very susceptible to changes in people's mindsets. Yáng (1988) examined popular conceptions of Yuanfen in traditional China through an analysis of historic anecdotes, tales, and early popular literature. Early on, the concept was sometimes thought to have mythological origins or to stem from reincarnation and karma. But most commonly, it was just perceived as an uncontrollable and deterministic factor that came into existence directed by higher powers.

Thus, in its substance, the concept of Yuanfen in traditional China was very similar to the concept of fate, a higher power that determines people's lives (Wenninger 2002c). Unlike fate, however, Yuanfen was believed to exert its influence mainly in the field of interpersonal relationships, where it could bring about good as well as bad results; the latter in the form of nièyuán 藮缘 or evil yuán (Yáng 1988).

No scientific evidence exists relating to the development of the concept during the twentieth century, including during the ideologically restrictive Mao era. However, it can be assumed that conceptions of Yuanfen persisted in people's minds even during ideologically restrictive times, that they changed slowly in keeping with social changes, and that they were able to thrive again after ideological control was loosened.

Empirical studies conducted in the PRC, Taiwan, and Hong Kong show that in contemporary China, the concept of Yuanfen has undergone interesting transformations corresponding to changes in people's world view. While levels of belief in Yuanfen are still high (Jing 2005; Yang and Ho 1988), ideas about the origins and the nature of the concept have changed.

First of all, while Yuanfen is still something which lies outside of the individual's grasp, many supernatural and fatalistic beliefs about its origins have receded. In a study conducted in the $1980 \mathrm{~s}$, for example, levels of agreement with proverbs

5 The second syllable fèn 分, derived from dingfèn 定分—predestination—was probably added to yuán to underline the fatalistic nature of the concept (Bái 2004). 
without supernatural elements like predestination and reincarnation were much higher than with proverbs containing supernatural elements (Yáng 1988).

Secondly, while in traditional China Yuanfen could be good-natured as well as bad-natured, it is nowadays perceived almost exclusively as good-natured, bringing about mostly positive outcomes (Yáng 1988; Chang and Holt 1991; Liú 2010).

Thirdly, the influence of Yuanfen is no longer limited to interpersonal relationships, but extends to relations with things like jobs, studies, hobbies, and interests (Yang and Ho 1988 and Jing 2005). In the realm of interpersonal relationships, Yuanfen is no longer commonly used for relations resulting from kinship or shared location, which were once attributed to the concept because they were perceived as predestined, but rather for relations that cannot be explained with familial bonds or other obvious causes (Yáng 1988 and Liú 2010).

Finally, unlike in earlier times, a Yuanfen encounter is no longer considered to have a deterministic influence on people's lives. Rather, its outcome is perceived as alterable through individual action. Yuanfen is perceived as a chance that one has to grasp and cherish in order for it to produce an effect; a chance that can otherwise also be forfeited (Yáng 1988; Chang and Holt 1991; Liú 2010). Two studies even discovered that some people think Yuanfen can be created by the individual (Zhāng and Zhōu 2004 and Jīng 2005), although the relevance of this statement remains largely unclear and therefore shall be further investigated in this paper.

This new leeway for the individual's contribution to the outcome of a Yuanfen encounter reflects a new semantic meaning that the two characters yuán and fèn have acquired in recent times. Yuán remains the uncontrollable chance by which people are brought together, but while fèn was originally added to yuán to underline the deterministic nature of the encounter, it is nowadays partly interpreted as the outcome of a relationship which depends on the individual (Bái 2004). Thus, today's concept of Yuanfen contains a fatalistic as well as a voluntaristic element. This dualistic meaning is expressed through sayings like 'yuán comes from heaven, fèn is man-made'—'yuán běn tiān chéng, fèn zài rén wéi' 缘本天成, 分在人为 or 'There is yuán, but no fèn'- 'yǒu yuán wú fèn' 有缘无分.

\section{Psychological and Social Functions of Yuanfen in Traditional and Con- temporary China}

In traditional Chinese society, life took place mainly within the primary group. The family and the clan were the most important social institutions, as well as, according to Confucian thinking, the pillars of a harmonious society (Guthrie 2006b). Yáng (1988) characterises this type of society as a form of 'clan-centered collectivism', 6

6 The English terminology in this section was taken from Yang and Ho (1988). 
which required a stable social structure in order to function. According to Yáng, the need to harmoniously coexist made people develop a 'social orientation' which consisted of 'group orientation' on the one hand and 'other orientation' on the other hand. 'Group orientation' refers to people's efforts to maintain solidarity and harmony in social interactions, especially within the primary group. 'Other orientation' refers to their efforts to present themselves to others in a light favourable to social harmony.

In this context, Yuanfen played an important and positive role not only for the individual, but also for society as a whole. Since Yuanfen was believed to be predestined by an external force, it was universally applicable to find explanations for different positive or negative relationship events. Attributing the causes for the formation, development, outcome, or lack of a relationship to the uncontrollable concept of Yuanfen rather than to personal effort or flaws not only protected the individual, but also others directly or indirectly involved in the relationship. It was a passive attribution, helping people accept their role in society and not break away from the primary group (Yáng 1988).

While social and family structures prevalent in traditional China changed relatively slowly after the revolution of 1911, big transformations were initiated by the Mao era (1949-1976) and the new era China entered through reform and opening in 1978. In today's market economy, after years of collectivisation and heavy state control, individuals are on their own in many areas of life (Guthrie 2006a-b).

After 1978, the loosening of state control and the disappearance of the safety nets of socialism on the one hand and market-oriented reforms on the other hand have compelled the individual to take the initiative and assume personal responsibility. This promoted a process of individualisation which had first started under Maoist socialism, ${ }^{7}$ when the individual was dis-embedded from traditional social categories (Yan 2010a). But while individualisation in Western Europe happened under the aegis of developed democracy and a welfare state and, as such, is institutionally anchored in a system of basic rights, the individualisation of Chinese society has been shaped by the gradual disappearance of the safety nets of socialism and an ongoing negotiation with the state over individual rights (Beck and Beck-Gernsheim 2010 and Yan 2010a-b). Therefore, individuality in China has not yet become a goal in and of itself, but often rather serves as a means of improving life chances (Yan 2010b).

Yáng (1988) estimated that in an individualised society, Yuanfen would gradually lose its social functions. However, no study has ever attempted to investigate this hypothesis. This is one of the research gaps the present study wishes to address. Assuming that in contemporary China, Yuanfen still functions on a social level, this

7 A multi-faceted portrayal of the processes of Chinese-style individualisation is provided by the book iChina: The Rise of the Individual in Modern Chinese Society, edited by Hansen and Svarverud (2010). 
paper will look at the concept in the social environment of university students in the PRC.

Considering the relatively limited number of studies on Yuanfen, they do nonetheless provide a considerable amount of evidence on the concept's psychological functions in contemporary China. According to research by Chang and Holt (1991) as well as Zhāng and Zhōu (2004), Yuanfen is still an important contextual factor in the formation and development of interpersonal relationships. As in traditional China, it still functions as a catalyst, with feelings of Yuanfen-no matter whether they are there from the outset, whether they develop over time or are discovered retrospectively - influencing people's decisions. But unlike in traditional China, people think that relationships can be actively worked on, irrespective of whether there is Yuanfen between them or not. Rather, the presence of the feeling of Yuanfen is taken as an impetus to actively grasp and cherish a chance; the idea that Yuanfen is precious and fleeting makes people work on a relationship even harder. Still, Chang and Holt (1991) point out that people are sometimes more likely to work on a relationship in the presence of Yuanfen and more likely to give up on it in its absence.

Despite the fact that people have become more ready to assume personal responsibility for the outcome of a relationship (Yang and Ho 1988), the attribution to Yuanfen is still used to rationalise relationships in a way that protects oneself and others. According to Chang and Holt (1991), the concept gives people the opportunity to define a relationship without having to bother with deeper reasons. For example, a lack of Yuanfen can be used as an excuse to reject unwanted admirers without hurting them.

Likewise, Yuanfen serves as an explanation for success and failure in personal performance. Dù (1999) discovered that Chinese high school students use Yuanfen and other nonmaterial concepts as a humble way of explaining their own success (thus avoiding attribution of success to personal factors), while it serves as a positive mechanism for coping with failure. Without denying their own responsibility, the attribution to Yuanfen helps students keep a positive attitude and encourages them to keep making an effort. Similarly, a study on victims of work accidents that had left them partly disabled discovered that Yuanfen, among other nonmaterial beliefs, can help people give meaning to tragic personal events and deal with them in a more optimistic way (Cheng 1997).

Through quantitative studies conducted in a working environment, Lǐ and Chén (2006 and 2007) found that in general, belief in Yuanfen correlates with practical intelligence, popularity within a group, subjective well-being, and job performance. Interestingly, the two components of the new, dualistic meaning of Yuanfen discussed earlier were shown to fulfil different functions. While fatalistic yuánattributions have a positive effect on subjective well-being, voluntaristic fènattributions have a positive effect on job performance. 
Finally, because of its meaning and its positive connotation, Yuanfen is often used for the purpose of attaining personal or economic benefits. On the one hand, it is used to establish and maintain guānxi 关系—interpersonal relationships with personal or professional benefits for the individual (Chǔ 2009). On the other hand, because the concept speaks to people, it is frequently and successfully used for the purpose of marketing, in the dating and marriage industry and in popular music (Cheng and Yau 2006).

\section{Theoretical Foundations and Contextualisation of the Empirical Study}

\section{The Framework of Cultural Psychology}

In order to analyse the psychological functions of Yuanfen in a situational context, it is important to adhere to the principles of cultural psychology. 'Culture allows people to know who they are, define what is meaningful, communicate with others and manage our environment' (Kim et al. 2006: 12). Hence, on many basic levels, culture influences our perception, thinking, and actions. However, we do not consciously realise these regulating functions because our own culture is taken for granted (Wenninger 2002a-b).

Given its undisputed significance for psychological processes, culture has traditionally been included as a variable in psychological studies. However, considering its fundamental importance in people's lives, the notion of culture as just one of many independent variables is often criticised. This is where cultural psychology as an independent scientific discipline wants to make a difference: Cultural psychology conceives all psychological phenomena as cultural constructs and thus doubts the universality of general, decontextualised psychological theories. On the contrary, it aims at understanding psychological phenomena in specific cultural, social, and historical contexts (Billmann-Mahecha 2002 and Kim et al. 2006).

An important demand of cultural psychology is to empirically validate psychological theories created in the West because they might not be valid in every cultural context. Attribution theory, which will be discussed in the following section, is a good example of this. Another demand is that psychologically relevant phenomena non-existent in Western cultures, e.g., concepts like Yuanfen, are made the focus of research (Yáng 1982a and Liú and Yáng 2008). In any case, the individual should be the starting point for all studies in the field of cultural psychology (Qí 2011). 


\section{Attribution Theory}

The term 'attribution' describes the psychological process of finding and explaining causes for behaviour and events. The aim of attribution theory is to systematically explain how and why attributions take place. Research on attribution was initiated by Fritz Heider (1958), ${ }^{8}$ who was one of the first to make folk psychology or commonsense psychology - the theories on which common people make sense of their lives and their environment - a subject of scientific psychological research (Bierhoff 2002; Meyer 2003). Other important contributions to attribution theory were made by Weiner et al. (1971; Weiner 1985) as well as Abramson at al. (1978).

Although attributions can be of different nature, they can generally be classified according to four dimensions: locus of control (internal or external: whether a perceived cause lies within or outside of the individual's space of action), stability (stable or unstable: whether a cause is perceived as stable over time), controllability (controllable or uncontrollable: whether a cause can be wilfully controlled by the individual) and globality (global or specific: whether a cause affects a wide range of situations or just specific ones). In order to determine the implications of an attribution for feelings and behaviour, the actual attribution is often less important than its position within these four dimensions (Bierhoff 2002 and Meyer 2003).

Even though an event almost always has multiple causes, they are very rarely all taken into account when an attribution is made (Bierhoff 2002). What is taken into account, however, strongly depends on the cultural context. For example, people from Western cultures tend to attribute behaviour and events primarily to internal factors, while people from Asian cultures tend to give greater importance to the situational and social context and are more likely to attribute events to external factors (Dù and Yuè 2011).

Likewise, the psychological implications of an attribution strongly depend on the cultural context. According to theories established in the West, the attribution of events to external factors like fate has negative effects on mental health, while the attribution to internal factors has positive effects (Bierhoff 2002). But these theories are only valid in cultural contexts where fate carries very fatalistic notions, implying powerlessness of the individual and excluding self-determination (Liu and Mencken 2010 and Norenzayan and Lee 2010). In fact, because fatalism and the belief in fate are not the same things (Raphals 2003), the belief in concepts like fate does not always have to go along with a fatalistic world view (Liu and Mencken 2010).

In the case of China, attributing events to external factors is not in conflict with self-determination. This phenomenon is explained by Lǐ Pèiliáng 李沛良 (1995) in his theory of 'fatalistic voluntarism'- 'sùmìng néngdòng guān' 宿命能动观. Fatalistic voluntarism is a culture-specific world view which acknowledges the existence

8 An extensive overview is given by Buchanan and Seligman (1995). 
of external forces, but at the same time emphasises the supremacy of willpower over these forces. On the one hand, nonmaterial beliefs help people explain and accept their destiny, but on the other hand, they encourage them to actively take their lives into their own hands. According to Ľ̌ , fatalistic voluntarism is a rational and functional world view which leads to an optimistic outlook on life. Lǐ uses the attribution to Yuanfen to underline his point: While the fatalistic element in Yuanfen would help people make sense of certain events, its voluntaristic element would encourage them to actively pursue chances (Lì 1995).

The positive functions of fatalistic voluntarism theorised by Lǐ were confirmed by more recent empirical studies. Among others, Chen et al. (2006) as well as Liu and Mencken (2010) empirically connected belief in fate and fatalistic voluntarism in China to mental health and subjective well-being.

\section{Yuanfen as an Attribution}

In Yáng's (1988) initial study on Yuanfen, with regard to traditional China, Yuanfen was categorised as an external, stable attribution (Yáng 1988). However, based on recent empirical evidence, the concept should nowadays rather be categorised as an external, but variable and controllable attribution. Yuanfen is still an external force that lies outside of the individual's space of action. Yet while people used to feel powerless in the face of events determined by Yuanfen, they now feel that they have ways to control the influence Yuanfen has on their lives.

In order to further understand Yuanfen as an attribution, it remains to be examined in which situational frameworks the concept provides explanations. This is where studies on fate-attributions can give some guidance. According to Pepitone and Saffiotti (1997), external, nonmaterial beliefs like fate, chance, luck or God are used selectively to explain life events. They discovered that fate is used to explain important events with significant positive or negative consequences for one's life, as well as for events that are perceived as unlikely. Burrus and Roese (2006) further discovered that fate serves as an explanation for abstractly construed, meaningful events that lie further in the past rather than for events with concrete causes, and that it is more likely chosen to answer questions about the 'why' than about the 'how' of events. Also, whether an event is attributed to fate depends less on the locus of control than on the perceived immutability of the event. Events attributed to fate are perceived as inalterable, as opposed to events which allow for counterfactual thinking ${ }^{9}$.

Whether these findings hold true for Yuanfen will be examined in the following.

9 Thinking about what could have gone differently. 


\section{Contextualisation of the Empirical Study}

The socio-cultural context in which the meaning and functions of Yuanfen are to be examined in the present study is student life at Chinese universities. Therefore, a basic understanding of the higher education system of the PRC and, most importantly, the situation of the students within this system, is needed.

The PRC made the step from elite to mass higher education as defined by Trow (1973) in just a decade. ${ }^{10}$ However, in terms of gross enrolment, China still lags behind more developed countries (Yao et al. 2010). In 2012, only 26.7 per cent of people in the corresponding age cohort were enrolled in tertiary education (UNESCO Institute for Statistics 2014).

In order to distribute the limited resources for higher education, a centralised enrolment system has been developed, the core of which is the gāokăo 高考, the national college entry exam (Qū and Lì 2010) which is held once a year nation-wide. However, this system is problematic for several reasons. First, even though meritocratic in theory, the gāokăo is not a just means of selection, most notably because of regional differences in the requirements for and the allocation of higher education entry (Yao et al. 2010; Zhāng and Yú 2010; Fàn 2011). Second, because there are only places to study for a limited number of people, the score reached in the gāokăo figuratively decides over the future of a considerable number of young people in China. This is expressed by the popular saying 'One exam determines one's whole life'- 'ȳ kăo dìng zhōngshēn'一考定终身 (Qū and Lǐ 2010: 89). Third, the current higher education entry system is not transparent. In the course of the examination process, candidates can list preferences for institutions and fields of study, but it is not guaranteed that these preferences will be granted. The outcome lies beyond the individual's scope of action, with government agencies allocating students to institutions and majors and students having no insight into the exact allocation mechanisms (Zhāng and Yú 2010).

Under these conditions, young people in China face a lot of psychological challenges. Education has traditionally had a high value in Chinese culture, ${ }^{11}$ with personal success and failure affecting the whole family. In today's competitive times when, due to the one-child policy, resources and hopes focus mostly on just one child, the pressure on young people is even higher (Haag 2012: 89ff). This pressure is heightened by the fact that for most parents as well as young people themselves, the goal is not only higher education per se, but entry into a prestigious institution (Zhāng and Yú 2010).

10 A comprehensive statistical account of the developments in the higher education system of the PRC is given by Zhu and Lou (2011).

11 An in-depth analysis of the 'educational desire' in China is provided by Kipnis (2011). 
If students manage to enter higher education, they are confronted with new psychological and social challenges. First of all, not everyone gets enrolled in their desired study program. According to a study by Liú Wéitíng 刘维婷 (2009), a third of all students reported dissatisfaction with their field of study, and almost half said you could do nothing but 'accept things as they are and make the best of it'- 'ji lái $z h \bar{l}, z e ́$ ' $\bar{a} n z h \vec{\imath}$ 既来之, 则安之 (Liú 2009: 48). Furthermore, far away from home, many have trouble adapting to their new environment and life on campus, often feeling lonely and lost. Because chances to visit home are rare, social interaction with fellow students and especially roommates plays an important role. Different regional and social origins, different habits as well as differences in character can be challenging for harmonious cohabitation (Liú 2009). Lastly, the increase in enrolment over the last decades has caused a situation where there are more qualified people than the economy needs (Wáng et al. 2012). Thus, many students have a rather pessimistic outlook on the future because they know about the struggles awaiting them in finding a job that suits them, or finding a job at all (Liú 2009).

In the present study, it is assumed that the concept of Yuanfen can help Chinese students deal with some of these challenges in a positive way.

\section{Research Design of the Empirical Study}

Based on the current state of research and the research gaps observed by the author, the main question this study set out to answer was: What are the meaning and functions of the concept of Yuanfen for university students in the PRC?

In order to obtain a comprehensive answer to this question, the following five sub-questions should be answered:

1. What are the prevailing conceptions of Yuanfen among students in contemporary China?

2. What kind of situations do Chinese students attribute to Yuanfen and why is Yuanfen used as an explanation in the respective situations?

3. What meaning does Yuanfen have for Chinese students and how do students perceive their own power to influence Yuanfen?

4. What psychological functions does Yuanfen have for students in the PRC?

5. Does Yuanfen, based on its functions for the individual, also have functions for society as a whole? 
Semi-structured, qualitative interviews were chosen as the main research method. A set of open-ended questions left room for reflection, subjective meaning, and anecdotes which would connect Yuanfen to students' personal experiences within their social context. During the interview process, the questions were used in a flexible manner, making it possible to follow each interviewee's individual train of thought (Chén 2000a-b). All interviews were recorded and transcribed verbatim in Chinese.

Altogether, 19 interviews (eleven with undergraduate and eight with graduate students) were conducted during a period of six weeks in the autumn of 2012. The interview partners were openly recruited through flyers on campus, which sometimes lead to snowballing. They were chosen through theoretical sampling (Chén 2000c). The first sampling criterion was to provide for a common background of experiences by assuring homogeneity regarding Chinese ethnicity and regular student status at the same university. The second and more important criterion was to achieve heterogeneity regarding all other factors like gender, age, field of study, degree programme (undergraduate or graduate), year, as well as regional and social background. This yielded a well-rounded sample for examining the meaning and functions of Yuanfen for Chinese students. ${ }^{12}$ The sampling took place parallel to the interview process and was terminated when saturation was reached.

The research location, East China Normal University (ECNU) in Shanghai, was chosen because of its diverse student population. As a prestigious institution, ECNU attracts students from all over the country, which provides for local diversity. Social diversity is guaranteed by the fact that as a teacher training institution-subsidised by government and with lower or remitted tuition fees (Yang and Gale 2005) ECNU facilitates access for students from weaker social backgrounds who otherwise would not be able to afford studying at a university of its rank. Lastly, notwithstanding its focus on teacher training, ECNU is a comprehensive research university with a diverse array of disciplines (ECNU 2012), so students with very different majors could be interviewed.

Five of the 19 interview partners formed a control group, which was added to the research design because participants in the regular sample could have been influenced by their knowledge of the research topic. Students in the control group initially were not told the study revolved around Yuanfen. Instead, they were asked to reflect on their student life, challenges, twists and turns in the time leading up to and during university, as well as on their world view (this was also the introductory part of the interviews with the regular sample). The intention was to see whether or not Yuanfen or similar concepts were mentioned even without prior knowledge of the research topic. In any case, the topic was revealed to the interviewees after this introductory part and the interviews continued as usual. Therefore, data from the

12 See appendix. 
regular sample and the control group met the criteria of comparability and could be analysed together unproblematically.

The interviews were analysed using Mayring's (2010) method of qualitative content analysis, a systematic, hermeneutic approach. The analysis was conducted with ATLAS.ti (2013), software suited to the needs of qualitative content analysis. As suggested by Mayring (2010), a system of categories served as the basis for interpretation of the data. Ten main categories were deduced from the five sub-questions of the study. Sub-categories, as fractions of answers to these questions, were generated inductively from the interview material using a systematic coding scheme ${ }^{13}$.

In addition to the student interviews, expert interviews were conducted to discuss preliminary results and new hypotheses. According to Meuser and Nagel (1991), anyone with privileged knowledge about the research topic or the target group is considered an expert. In that sense, a professor in the field of higher education, a professor in the field of psychology, a psychological student counsellor, and a person working in administration and student counselling at ECNU were interviewed.

\section{Results of the Empirical Study}

\section{Conceptions of Yuanfen}

Although Chinese students have one common concept in mind when they talk about Yuanfen, there are many different views as to its actual nature. The different conceptions came to light in an implicit way, both when students were asked to talk about what Yuanfen was to them, which they often did using idioms and proverbs, and when they were asked to share anecdotes about personal experiences related to the concept. Altogether, nine distinct nuances in the conception of Yuanfen could be identified:

1. A precious chance or present, given by heaven (the emphasis here is on the involvement of heaven, in contrast to the general definition of Yuanfen as a chance that brings people or people and events together).

2. Something positive that had a very small probability of happening, as opposed to a much bigger probability of it not happening (e.g., meeting just the right person in just the right place at just the right time).

13 To examine the coding scheme (in German), please consult the author's Master's thesis (Heger 2013): http://othes.univie.ac.at/30238/. 
3. An important, positive turning point discovered in retrospect without which one's life would not have been the same (for example, without having to retake the gāokăo, which was frustrating at first, one would not be right here right now and would not have met some of one's closest friends).

4. Something that has come into being through idealistic thinking, which is expressed by the saying 'yuán comes following a wish, only based on a wish will there be yuán'_‘yuán lái suí yuàn, yuàn yǒu yuán' 缘来随愿 愿有缘.

5. Something that just 'follows the course of nature'—'shùn qi zirán' 顺其 自然.

6. A just and positive, though not predictable, reward for personal effort in the sense of a cause-effect-relationship (for example, if one has given one's best to get enrolled in a certain university, and the actual outcome is not the one originally hoped-for, but turns out to be a very positive one).

7. A secondary cause which helps the primary cause-personal effortbear fruit. This is expressed by the proverb ' 30 per cent are destined by heaven, 70 per cent are achieved through personal struggle'—'sān fên tiān zhùdìng, qī fēn kào dăpīn' 三分天注定, 七分靠打拼.

8. A 'necessity within the contingency [of things that could happen]''óurán zhōng de bìrán' 偶然中的必然—the realisation of which requires a specific act by the individual. Two interview partners gave the following example: Only dialling the phone number on the author's flyer saying 'looking for interview partners' could lead to the necessary Yuanfen encounter between author and interview partner.

9. An encounter in itself, which has not yet taken on any deeper meaning, but can be the start of something.

In addition to these nine nuances, some students also brought up nièyuán or evil yuán. However, it became clear that nièyuán is not perceived as a nuance of Yuanfen, but rather as a less important counterpart to it. Finally, an interesting observation is that Yuanfen remained very abstract in the mind of those students who had not attributed any personal experiences to the concept yet, leading to the conclusion that a personal conception is dependent on personal experience attributed to Yuanfen. 
The conceptions identified above share certain characteristics, for instance in terms of the point in time in which an attribution is made (retrospectively, in the moment of the event, or prospectively) as well as with regard to the individual's perceived power to influence the coming into existence of Yuanfen. Both are important in terms of the psychological functions of the concept and will be addressed later.

\section{Situational Frameworks and Reasons for Yuanfen-Attributions}

The things Chinese students attributed to Yuanfen can be put into three different categories: 1) interpersonal relationships (friends, intimate relationships including past relationships and hypothetical future relationships, new encounters including encounters with people from foreign countries, the unexpected reunion with old acquaintances, faraway encounters with people from the same hometown, classmates, roommates, and teachers); 2) important events in the course of one's life (related to one's studies, the institution where one studies, one's hypothetical career and other future life events, as well as one's social circumstances); 3 ) other things like ideas, hobbies, interests, and even the contents of movies.

All of the relationships or events attributed to Yuanfen have three common characteristics. First, they are positive or are perceived as positive by the individual even though they might not always have gone the way one had hoped they would. Purely negative events are, if at all, attributed to a lack of Yuanfen. Second, they all have subjective meaning. Third and most importantly, they all have something uncontrollable, inexplicable or at least not rationally explicable about them - an element of chance that can best be grasped by the Chinese term ǒurán 偶然, which was used very frequently by the interviewees. Even if there were rational explanations at hand, it seemed that Yuanfen could provide additional explanations and thereby emphasise the positive meaning of the attributed relationships and events.

A good example of the situational frameworks in which Yuanfen may serve as an explanation is provided by how the interview partners attributed their journey that led to studying at ECNU. Journeys that went completely as planned or were entirely dissatisfactory were never attributed to Yuanfen. Only journeys that turned out differently than planned but were perceived as positive in retrospect were, next to other factors like the score in the gāokăo, reasons lying within the higher education system or personal reasons, attributed to the concept. The fact that journeys that had not gone the ideal way were only ever attributed to Yuanfen in addition to other reasons shows that finding explanations in Yuanfen does not conflict with assuming personal responsibility. An exemplary situation was the situation of being allocated to a field of study not even listed in the interview partner's preferences, ${ }^{14}$ but which,

14 The Chinese term for this common phenomenon is bèi tiáojì 被调剂. 
contrary to expectations, he or she learned to love over time. A female interview partner put it like this:

Actually, I often think back on it [how my academic journey came about], it's just like, it's just like a 'blessing in disguise' [...]. So I think, [the fact] that in the beginning it wasn't as I had wished, that after a while I slowly started liking it, and that now I have accepted and learned to love this field (major), I think, I think this must be some kind of arrangement made by heaven. ${ }^{15}$

There were different reasons for students choosing Yuanfen as an explanation, which surfaced implicitly during the interviews: a search for sense and reasons; an inexplicable feeling of affinity and connectedness; the occurrence of something which directly corresponds to one's own conception of Yuanfen; and finally a conscious decision to make use of the positive functions of Yuanfen. Less frequently, events were attributed to Yuanfen because of popular beliefs (for example, about zodiac signs) or in order to find an excuse.

\section{The Meaning of Yuanfen for Chinese Students and Beliefs About the Individual's Power to Influence Yuanfen}

The meaning of Yuanfen for Chinese students has to be analysed against the backdrop of their world view and their attitude towards life, which came to light during the interviews. Without exception, the interview partners considered personal effort to be the single most important and determining factor in life. They believe that people can achieve what they want to achieve within the bounds of possibility, but in addition to that, they integrate nonmaterial beliefs into their world view to greater or lesser extents. A female interview partner compared concepts like Yuanfen with seasoning:

[...] for example, if you are preparing a dish, if you don't have salt or spices like that, the dish isn't a dish yet, it is a very important seasoning, but too much of it isn't good, either, it has to be the appropriate amount. ${ }^{16}$

Only one male interviewee tried to consciously exclude nonmaterial beliefs from his life because according to him, they would lead to passivity. This, he expressed through the idiom 'To guard a tree-stump, waiting for rabbits'—'shǒu zhù dài tù' 守 株待兔:

15 其实很多时候回想一下, 就是说, 就是 ‘塞翁失马, 焉知非福, 【。。」。所以我觉得一开始的不 如意, 到后来慢慢喜欢, 到现在我接受并且热爱这份专业, 我觉得, 觉得就是上天的安排和注定。 (interview 2) For an overview of all interviews, please see appendix.

16 【。」】就比方说做一道菜你没有盐这样的调料, 这道菜就不是菜了, 就是很重要的一个佐料, 但是多了又不行，但一定要是最恰当的。(interview 7). 
[...] he [the man in the proverb] probably thought that this kind of Yuanfen would continuously occur, so he slept there every day without doing anything, waiting for a rabbit to bump into the tree [as it had happened by chance once before], but obviously it wouldn't be like that. But a lot of people just have this kind of attitude, they just wait for a good thing to fall into their lap. ${ }^{17}$

Based on the general acknowledgement of nonmaterial beliefs as part of life, all interview partners explicitly stated that they believed in Yuanfen. However, it also became apparent that the degree of belief in the concept varied from student to student. Some of the interview partners frequently integrate Yuanfen into their everyday lives, while others rarely or never think about it outside of the interview situation.

This observation was especially apparent in the interviews with the control group. These interviews demonstrated that if nonmaterial beliefs did, to some extent, have meaning for the interviewee, they were addressed even without prior knowledge of the research topic, which happened three out of five times. The other two times, nonmaterial beliefs were not addressed, and in fact, even after revealing the research topic, the two students did not attribute any events in their lives to such beliefs.

In terms of the functions Yuanfen has for Chinese students, it is thus important to note that individual meaning and not an abstract conceptualisation is the decisive factor. In most cases, a stronger belief in Yuanfen correlates with a greater meaning and vice versa. Nevertheless, one female interview partner stated that even though her belief in the concept was not very strong, she intentionally gave it meaning in her life because she considered it important in many situations:

It's just that I don't really believe in it [Yuanfen] too much, because I think-actually, I think that I should believe in it. [...] It's just that I think in some areas, one has to believe in it. For me, I think I very much believe in things I can see, if I don't see it I just don't believe in it, it's like that. [...] It's just that in many situations, it [Yuanfen] is really very important, for example my roommate, that she and I are living together is Yuanfen, our encounter was Yuanfen. Between friends you really need it, and between lovers you also need Yuanfen. ${ }^{18}$

Based on these observations, it can be concluded that if Yuanfen is given meaning by the individual, its role is perceived as positive and active. These two attributes are

17 【。。】他会觉得说这种缘分是可以不断出现的, 所以他每天都在那里睡觉什么事情也不做就等 着兔子来撞树上, 但是显然就不会这样子的。但是很多人就是抱着这种心态的, 就是他是在等待一 个好的事情来降临到我身上。(interview 9).

18 就是我真的不太相信, 因为我觉得一一其实我应该相信我觉得。【。。】就我觉得就是有的方面 是需要相信的。就是就我这个人吧, 我觉得就我还蛮相信我看到的东西, 如果我看不到我就不太相 信这样子。【。。】就是在很多当中就真的很重要, 比如说我的室友吧, 她和我住在一个地方就 是缘分, 就是我们的相遇就是一种缘分。朋友之间真的很需要, 然后爱人之间也很需要缘分。 (interview 15). 
both comprised by the Chinese term jiji 积极, which students frequently used to describe the concept.

As to the individual's power to influence Yuanfen, the interviewees unanimously thought that Yuanfen could never be directly controlled or created. Therefore, how and when Yuanfen enters your life would always be somewhat random. But there were different ideas as to whether and how the individual can influence Yuanfen. Some thought that chances for Yuanfen entering your life can be created through individual action, for instance by actively going out and looking for contact with other people or by actively striving after an academic or professional goal. One female interview partner gave the following example:

\begin{abstract}
I think you can say that Yuanfen is also something that you can create. Because some, for example, just taking the many boys and girls nowadays who never go out, just the phenomenon of there being a lot of 'leftover women', it's just because they always stay inside their own home and don't go expanding their circle of friends, they certainly will be single. But I think, if they just step outside the door, interact with people, or make finding friends their priority, then they will probably encounter their own Yuanfen. ${ }^{19}$
\end{abstract}

Others thought that even though you cannot actively create chances, you indirectly and unconsciously create a platform for Yuanfen by everything you do in life. Still others thought that you can only encounter Yuanfen, but there is no way of influencing it through your actions.

Finally, no matter how it has come into being, students believed that they could determine the impact Yuanfen has on their own lives. If Yuanfen presents itself, you can (and in most cases will) actively grasp and cherish it, but you can also decide not to pursue it or to just let it take its course and see what happens.

\title{
Psychological Functions of Yuanfen for Chinese Students
}

Throughout the interviews, it became apparent that for Yuanfen to have psychological functions, it has to be given meaning by the individual. This, in turn, has to lead to an attributional process in which relationships or events are linked with the concept. If the condition of individual attribution is fulfilled, Yuanfen has very positive functions for Chinese students. Furthermore, the degree to which Yuanfen is given meaning by the individual is related to the extent to which the concept fulfils psychological functions. Conversely, if Yuanfen does not have meaning for the individual, it does not have any psychological functions for that person either.

19 我觉得缘分应该来说应该也是可以创造的吧。因为, 有些, 像比方说, 就, 就拿我们现今的很多宅 男宅女, 就是很多剩女现象, 就是因为她们老是宅在自己的家里, 不出去拓宽自己的朋友圈子, 那 肯定就会变成单身, 但是我觉得, 她只要踏出家门, 然后多去自己多去社交, 或者是交朋友为主, 那她这个时候就可能会碰上她自己的缘分。(interview 2). 
Because of the common characteristics shared by several of the conceptions of Yuanfen, different conceptions can have similar functions. For one thing, certain conceptions are more often related to retrospective attributions, while others are more often related to attributions in the moment of the event or to prospective attributions. For another thing, the individual's perceived power to influence Yuanfen varies between conceptions, with some people thinking that Yuanfen can be indirectly created or unconsciously induced through personal actions, while others think they have no way of creating Yuanfen whatsoever.

The most common function of Yuanfen identified through the interviews is that it contributes to a positive attitude towards different relationships and situations and makes students deal with them in a positive and cherishing way. On the one hand, the attribution to Yuanfen increases students' willingness to engage in new relationships, on the other hand, it prompts them to make an effort to cherish existing relationships. In that way, it plays an important role in the formation and development of interpersonal relationships. Also, the thought of Yuanfen can sometimes give students an incentive to actively go looking for new encounters and experiences.

Another common function of Yuanfen is that it retrospectively leads students to a positive perception of relationships and events in their lives. For one thing, the attribution to Yuanfen gives an even more positive and more special meaning to positive relationships and events. For another thing, it gives events and relationships (including past intimate relationships) that did not turn out the way one had hoped for, but that one has learned to accept in a positive way, additional sense and meaning that cannot be provided by objective reasoning. One example of this is the case of a failed relationship, which can still be attributed to Yuanfen. The memory of the precious chance that has brought two people together is not tainted by the bad outcome of the relationship, which once again highlights the dual nature of the modern concept (see last paragraph in the section "Changing Conceptions of Yuanfen Over the Course of Time").

Other frequently identified functions are of a prospective nature. If students think that personal actions can indirectly create Yuanfen, it gives them an impetus to go out and create chances, as well as confidence that personal effort will pay off in one way or the other. Also, the thought of Yuanfen makes students anticipate unforeseeable events lying in the future instead of dreading what they cannot control. The belief that Yuanfen is out there, that it could enter one's life at any time and that it will be positive, gives students hope and a calmer attitude towards the future. A male interviewee painted the following scenario:

If I let you work 29 days a month and let you rest one day, you will think, wah, this is hard. [...] But if, all of a sudden, you come across some funny or interesting things, or if you suddenly find a person with whom you get along very well [...]. What I mean is that if you believe in the existence of this thing [Yuanfen], it will often come very unexpectedly [...]. Actually, this thing, no matter if in the present or in the future, is always a very good thing 
for our lives. Because, because life, a life that is always the same is more boring than anything else. ${ }^{20}$

The attribution of unsatisfactory situations like the lack of a partner to a lack of Yuanfen was seen to have positive functions as well. On the one hand, this attribution lets students accept their situation in a more positive way, on the other hand, it makes them persevere in their search for Yuanfen. A male interview partner explained how he was dealing with the fact that he had not found a girlfriend yet:

\begin{abstract}
And then there are people who, if they haven't yet encountered it [love], they will say, ah, Yuanfen hasn't arrived yet. That makes them persevere a little bit more. I am one of those people, I just think that Yuanfen has probably not arrived yet. If, every time, either you don't go, or sometimes you anxiously go, see your classmates who are already dating or something, you will worry about dating yourself. But because [you acknowledge that] your situation is different from everyone else's, you will, you will rather hold on to this attitude. $^{21}$
\end{abstract}

Finally, a very interesting finding is that more than a few Chinese students are aware of the positive functions that Yuanfen has on their perception and actions. Furthermore, in order to induce these functions, they would sometimes consciously attribute relationships and events to Yuanfen.

\title{
Social Functions of Yuanfen
}

According to the results of this study, not all functions of Yuanfen on an individual level are also important on a social level. However, the two most common functions of the concept were shown to have a strong social component.

A university campus is a place where many people with different characters and backgrounds come together and have to live together, which is why interpersonal relationships play a key role. Under these circumstances, the impetus Yuanfen gives students to make an effort and deal with other people - even people you do not have a lot in common with (but who have come into your life anyway) - in a positive way can contribute to a harmonious communal life.

20 我如果让你一个月工作 29 天, 休息一天, 那你一定会觉得, 哇, 这个好沉重。【。。」但是你 如果突然遇到一些比较好玩的事情, 或者是突然找到一个人非常说得来【。。。】。我的意思就是 说如果我们相信这个东西【缘分】的存在, 那么它往往会来得很不经意【。。。】。其实这个东西 对于我们生活不管是现在还是未来, 它都是一个挺好的东西。因为, 因为生活吗, 一成不变的生活 比其它的什么东西都要无聊。(interview 5).

21 还有的人就是【爱情】没有遇到的时候, 他就会说, 啊, 缘分还没到。就会自己再坚持一下。我就 属于这种, 就是我自己觉得缘分可能还没有到。如果, 就是每次, 不会去去, 有时候会去着急去, 看待你周围的同学在谈恋爱或者什么, 你自己也着急去谈。因为你自己的情况和他们不同, 所以你 会, 就是还是会把握住这个度。(interview 4). 
The best example of these social functions, which was given by several interview partners, is the situation of getting along with roommates in the dormitory. According to the students, you cannot control who you will end up with as your roommate. But if you attribute this encounter to Yuanfen - whether out of true belief or because of a conscious decision - this will make you actively try to establish a harmonious relationship with the other person. A female interview partner put it like this:

The mindset of me and my roommate is totally different. [...] But we get along very well, and that's because, because, actually, you can also explain this with Yuanfen, because I think that since she is my roommate, no matter if it was her or someone else, I think that as long as she is my roommate, as long as we live together, then we, I can find something that is very valuable in her, and many, many good things. If you don't think that way, you will just very easily see her flaws. ${ }^{22}$

Furthermore, it was shown that the attribution to Yuanfen or to a lack of Yuanfen makes students perceive events in their life in a more positive way, giving them sense and additional meaning. This is especially relevant for events which do not correlate with personal wishing and planning due to the opaque workings of the Chinese higher education system. For instance, Yuanfen provides a positive mechanism for dealing with uncontrollable situations like the fact that students cannot fully take the decision of where to study and what to study into their own hands. The attribution to Yuanfen enables students to look favourably on their own circumstances instead of complaining about the system or questioning it. In this way, it contributes to social stability by reducing discontent and protest that might have further political implications.

\section{Discussion}

By analysing Yuanfen embedded in the social context of Chinese university students, the present study was able to gain valuable new insights into the meaning and functions of the concept in contemporary China. The contributions made by this study can broadly be classified into findings about the meaning, psychological functions and conceptions of Yuanfen, about situational frameworks for Yuanfenattributions, and about the functions of the concept in contemporary Chinese society. In the following, these results will be discussed in relation to the three hypotheses on 1) positive functions for the individual, 2) Chinese student life as fertile ground for

22 我跟我室友的想法 totally different。【。。】但是我们两个相处得很好, 是因为, 因为其实也可 以用缘分来理解, 因为我觉得既然做我的室友, 无论是她还是别人, 我觉得是只要她是我的室友, 只要我们在一起生活, 那我们, 我就可以从她身上找到 something that is very valuable, 然后非常 有, 非常好的地方。如果你没有这种想法的话你就会很容易看到她的缺点。(interview 1). 
Yuanfen-attributions, and 3) positive functions for society that were established in the beginning of this paper.

1) The most important finding of this study is the following: In contemporary China, Yuanfen does not have universal meaning, but only ever individual meaning. Furthermore, the meaning given to the concept on an individual basis is essential in order for it to have psychological functions. If Yuanfen is not given any meaning by the individual, it has no functions whatsoever. If Yuanfen is given meaning by the individual, and if this leads to a process of attributing relationships and events in one's life to the concept, it has a very positive impact on the lives of Chinese students. However, the role of Yuanfen is always seen as secondary to the role of personal effort, which, for all interview partners, is the determining factor in life.

Thus, according to the results of this study, the first hypothesis was proven to be true: If relationships and events are attributed to Yuanfen by a student, this attribution has positive functions for him or her, the nature of which depends on the individual conception of Yuanfen, the time of attribution (retrospectively, in the moment of the event, or prospectively) and the individual's perceived power to create Yuanfen. Even though students all think that Yuanfen can never be directly created or controlled, there are different views as to the degree to which one can influence its coming into existence: You can either actively create chances for Yuanfen, indirectly create Yuanfen through your actions, or not influence it beforehand at all.

On this basis, the actual functions of Yuanfen are manifold. Most importantly, the attribution to Yuanfen makes students open for new encounters and experiences, lets them cherish relationships, and prompts them to make an active effort to maintain them. This is even true for relationships that are not formed by choice and that sometimes present a challenge.

Furthermore, the concept has some important functions for retrospective meaning making. It provides explanations when objective reasons are hard to find, thereby bestowing the attributed events with a particularly positive meaning and additional sense. Retrospectively attributing relationships and events to Yuanfen either further emphasises their positive nature or, in the case of situations that have not gone the ideal way, highlights their positive elements as opposed to the negative ones.

In addition to its functions for dealing with past and present relationships and events, Yuanfen was shown to have a lot of prospective functions. Against expectations, many interview partners mentioned that the thought of Yuanfen gives them a positive and hopeful outlook on their future, sometimes even based on the view that it comes into your life by means of personal action. The idea that even though you cannot control how and when Yuanfen will affect your life, but that it could present itself at any time and that it will bring about positive outcomes, makes students anticipate challenges that cannot be planned or foreseen instead of dreading them. 
This is a very interesting new finding that has not been recorded by previous research.

Finally, another unexpected finding regarding the psychological functions of $\mathrm{Yu}$ anfen is that some students are well aware of the positive functions Yuanfen has on their perception and actions as well as for maintaining harmonious relationships. What is more, in order to induce these functions, students would sometimes consciously attribute relationships and events to Yuanfen. This leads to the conclusion that among Chinese students, the fatalistic element in Yuanfen is further receding, while the voluntaristic element is gaining importance, creating a shift in the relation of fatalism and voluntarism proposed by Lǐ̀s (1995) theory of fatalistic voluntarism.

2) In addition to new insights into meanings and functions of Yuanfen, this study was able to gain a deeper understanding of the situational frameworks of Yuanfenattributions. This makes it possible to discuss the second hypothesis according to which the special circumstances of Chinese student life provide fertile ground for this kind of attributions.

The findings showed that all the things attributed to Yuanfen have three common characteristics: First, they have personal meaning. Second, they are positive or are perceived as positive in the end even though they did not turn out the way one had planned them in the beginning. Third and most importantly, they are inexplicable or not sufficiently explicable through rational reasons.

Based on these findings, the second hypothesis is assumed to be true. At university, far away from home and after years of just focusing on studying for the gāokăo, students are confronted with many meaningful new experiences, new challenges and, most importantly, new encounters with people from all over the country or even the world. The social environment of a university campus thus generates a lot of situations which are hard to explain through obvious reasons. Besides, the higher education system of the PRC creates many situations that the individual cannot foresee or control. Lastly, during the time spent at university, students are confronted with their own, uncertain future in terms of private as well as professional life. Under all of these circumstances, the concept of Yuanfen can provide mechanisms for explanation and adaptation as well as positive thinking and action.

A better understanding of the situational frameworks of Yuanfen-attributions also aids discussion of the comparability of Yuanfen-attributions and fate-attributions ${ }^{23}$. In the case of both fate and Yuanfen, it is not an external locus of control, but rather the abstract construal and the meaningfulness of an event that are decisive for the attribution. But while fate serves as an explanation for positive as well as negative life events, the events attributed to Yuanfen are positive or perceived as positive. Also, events and relationships attributed to Yuanfen do not commonly lie further in

23 As outlined by Burrus and Roese (2006) as well as Pepitone and Saffiotti (1997). 
the past, as Burrus and Roese (2006) discovered for fate-attributions, but can also lie in the present or even in the future.

But by far the most important difference is the perceived mutability of the attributed events. According to Burrus and Roese (2006), events attributed to fate are perceived as inalterable. In contrast, Chinese students' narratives showed that in terms of the events attributed to Yuanfen, 'counterfactual thinking'-imagining alternative outcomes - is very common. Yuanfen is not perceived as a factor because of which an event or relationship was determined to happen, but rather as a factor without which a particular encounter might not have happened, and thanks to which it did. The attribution to Yuanfen thus gives meaning to one particular encounter as opposed to all possible alternatives. These findings correspond to insights into counterfactual thinking as gained by Kray et al. (2010). ${ }^{24}$

3) Finally, by analysing the concept of Yuanfen within the social context of Chinese students, this study was able to gain insights about its functions in contemporary Chinese society. Based on these insights, the third hypothesis, according to which the positive functions of Yuanfen for the individual have an impact on Chinese society as a whole, can be discussed.

The findings of the present study disprove Yáng's (1988) hypothesis according to which Yuanfen would lose its social functions in a more individualistic society. In the context of Chinese student life, Yuanfen appears to have lost its social functions as a passive attribution, but has gained new social functions due to its new, active nature. According to Yan (2010b), in spite of people being increasingly disembedded from cultural traditions and encompassing social categories, traditional concepts can still play an important role if they serve as a resource for the individual. As shown by the results of this study, Yuanfen, if given individual meaning, can serve as a resource in many social situations - for instance, when faced with new forms of collective living or when having to deal with areas of life that are beyond personal control.

Interviews with Chinese students showed that while not all functions of Yuanfen on an individual level are also relevant on a social level, the concept does have considerable social impact. On the one hand, the way in which Yuanfen guides students to make an effort and cherish interpersonal relationships contributes to a harmonious communal life on campus. On the other hand, by helping students deal with situations within the higher education system that are beyond their control in a

24 They found that counterfactual thinking heightens the meaningfulness and the positive perception of important life experiences and thus increases life satisfaction. Mentally subtracting important events or relationships from one's life paradoxically enhanced the perception that they were meant to be or fated, which again endowed them with deeper meaning. 
positive and active way instead of questioning the system, Yuanfen contributes to maintaining social and political stability.

However, as students are hardly ever representative of a country's total population - which is especially true for China, where there are big differences between generations and social groups - the third hypothesis has to be relativised in the sense that no conclusions can be drawn from these results for Chinese society as a whole. Taking into account the social circumstances as well as the modern world view of Chinese students, it can be assumed that the positive, active, non-deterministic, and sometimes even conscious role of Yuanfen for the individual, as well as the social functions derived from it, might be a special characteristic of the examined target group and cannot be transferred to other social contexts of contemporary China. In order to gain a more comprehensive understanding about the meaning and functions of Yuanfen for the individual and society in contemporary China, future research should extend its scope to different generations and social groups. 


\section{REFERENCES}

Abramson, Lyn Y., Martin E. P. Seligman, and John D. Teasdale. "Learned Helplessness in Humans: Critique and Reformulation.” In Journal of Abnormal Psychology, 87/1, 1978, pp. 49-74

ATLAS.ti GmbH. ATLAS.ti. Version 7.0.92, Berlin: ATLAS.ti GmbH, 2013

Bái, Hóngzhōng 白宏钟. “Jiănxī ‘yuán’ yǔ “yuánfèn’ de wénhuà yìyi” 浅析 “缘” 与 “缘分” 的 文化意义 [Analysing the Cultural Meaning of 'Yuán' and 'Yuánfèn']. In Nánkāi yǔyánxué $k \bar{a} n$ 南开语言学刊 [Nánkāi Linguistics], 1, 2004, pp. 125-133

Beck, Ulrich, and Elisabeth Beck-Gernsheim. "Foreword: Varieties of Individualization." In iChina: The Rise of the Individual in Modern Chinese Society, edited by Mette Halskov Hansen and Rune Svarverud. Copenhagen: Nordic Institute of Asian Studies (NIAS), 2010, pp. xiii-xx

Bierhoff, Hans-Werner. “Attribution.” In Lexikon Der Psychologie, CD Edition 5, edited by Gerd Wenninger. Hessisch Lichtenau: EDV-Verlag Saage, 2002

Billmann-Mahecha, Elfriede. "Kulturpsychologie.” In Lexikon Der Psychologie, CD edition 5, edited by Gerd Wenninger. Hessisch Lichtenau: EDV-Verlag Saage, 2002

Buchanan, Gregory McClell and Martin Seligman, eds. Explanatory Style. Hillsdale, New Jersey: Lawrence Erlbaum Associates, 1995

Burrus, Jeremy and Neal J. Roese. "Long Ago It Was Meant to Be: The Interplay Between Time, Construal, and Fate Beliefs." In Personality and Social Psychology Bulletin, 32/8, 2006, pp. $1050-1058$

Chang, Hui-Ching and G. Richard Holt. "The Concept of Yuan and Chinese Interpersonal Relationships." In International and Intercultural Communication Annual, Vol. 15: Cross-Cultural Interpersonal Communication, edited by Stella Ting-Toomey and Felipe Korzenny. Thousand Oaks: Sage Publications, 1991, pp. 28-57

Chen, Sylvia Xiaohua, Fanny M. Cheung, Michael Harris Bond, and Jin-Pang Leung. "Going Beyond Self-esteem to Predict Life Satisfaction: The Chinese Case." In Asian Journal of Social Psychology, 9/1, 2006, pp. 24-35

Chén, Xiàngmíng 陈向明. “Făngtán” 访谈 [The Qualitative Interview]. In Zhì de yánjiū fāngfă yǔ shèhui kexxué yánjiū 质的研究方法与社会科学研究 [Qualitative Research in Social Sciences]. Běijīnng 北京: Jiàoyù kēxué chūbănshè 教育科学出版社, 2000a, pp. 165-180

Chén, Xiàngmíng 陈向明. “Făngtán zhōng de tíwèn” 访谈中的提问 [On Asking Questions in Qualitative Interviews]. In Zhi de yánjiū fāngfă yŭ shèhui kēxué yánjiū 质的研究方法与社会 科学研究 [Qualitative Research in Social Sciences]. Běijīng 北京: Jiàoyù kēxué chūbănshè 教 育科学出版社, 2000b, pp. 182-193

Chén, Xiàngmíng 陈向明. “Yánjiū duìxiàng de chōuyàng”研究对象的抽样 [On Sampling in Qualitative Research]. In Zhì de yánjiū fāngfă yǔ shèhuì kēxué yánjiū 质的研究方法与社会科 学研究 [Qualitative Research in Social Sciences]. Běijīng 北京: Jiàoyù kēxué chūbănshè 教育 科学出版社, 2000c, pp. 103-115

Cheng, Simone C. L. and Oliver H. M. Yau. "Yuan (緣): The Case of Chinese Pop Songs.” In Asia Pacific Management Review, 11/5, 2006, pp. 331-340

Cheng, Y. H. "Explaining Disablement in Modern Times: Hand-injured Workers' Accounts of their Injuries in Hong Kong." In Soc Sci Med., 45/5, 1997, pp. 739-750 
Chǔ, Jīnqiáo 楚金桥. “Shāngwù huǒbàn guānxi shìyě zhōng de rénjì guānxi jí qí y̌̌ngxiăng yīnsù - jīyú zhōngguó wénhuà bèijǐng de fēnxī” 商务伙伴关系视野中的人际关系及其影响因素一 一基于中国文化背景的分析 [Factors Affecting Business Partner Relationships Within the Chinese Cultural Context]. In Hénán shīfàn dàxué xuébào 河南师范大学学报 [Journal of Hénán Normal University], 36/3, 2009, pp. 112-118

Dù, Línzhì 杜林致. "Rènzhī guīyīn de wénhuà bèijǐng jí qí chāyìxìng - jiān zhōngguórén guīyīn móshì yánjiū” 认知归因的文化背景及其差异性一一兼中国人归因模式研究 [Cultural Background and Cultural Differences Concerning Cognitive Attribution: A Study on the Attributional Style of Chinese People]. Ph.D. Thesis, Nánkāi dàxué 南开大学 [Nánkāi University], 1999

Dù Línzhì 杜林致 and Yuè Guó’ān 乐国安. “Xīfāng guīyīn lǐlùn de wénhuà fănsī” 西方归因理论 的文化反思 [Cultural Reassessment of Western Attribution Theory]. In Xīnlǐxué jìnzhăn 心理 学进展 [Advances in Psychology], 1, 2011, pp. 7-12

ECNU. “About ECNU: Overview.” 2012, East China Normal University website, http://english.ecnu.edu.cn/s/191/t/339/p/10/c/4568/d/4574/list.htm, accessed March 2013

Fàn, Guāngjī 范光基. "Wǒguó gāokăo zhìdù de lìshǐ yănbiàn jí qí duì xiàndài gāokăo găigé de qishi” 我国高考制度的历史演变及其对现代高考改革的启示 [The Historical Evolution of China's College Entrance Examination System and Its Revelations for the Reform of the Modern College Entrance Examination]. In Fújiàn jiàoyù xuéyuàn xuébào 福建教育学院学报 [Journal of Fújiàn Institute of Education], 3, 2011, pp. 76-81

Guthrie, Doug. "Changing Life Chances." In China and Globalization: The Social, Economic, and Political Transformation of Chinese Society. New York: Routledge, 2006a, pp. 175-215

Guthrie, Doug. "Changing Social Institutions." In China and Globalization: The Social, Economic, and Political Transformation of Chinese Society. New York: Routledge, 2006b, pp. 73-112

Haag, Antje. Versuch über die moderne Seele Chinas: Eindrücke einer Psychoanalytikerin. Second Edition. Gießen: Psychosozial-Verlag, 2012

Hansen, Mette Halskov and Rune Svarverud, eds. iChina: The Rise of the Individual in Modern Chinese Society. Copenhagen: Nordic Institute of Asian Studies (NIAS), 2010

Heger, Isabel. 'Die Bedeutung des Konzepts von 'Yuanfen' für die Geisteshaltung von Studierenden der VR China : eine qualitative Untersuchung mit Studierenden der East China Normal Unviersity." M.A. Thesis, Universität Wien, 2013

Heider, Fritz. The Psychology of Interpersonal Relations. New York: John Wiley and Sons, 1958

Jīng, Sù 经素. “Zhōngguórén de 'yuán': yì zhǒng wénhuà xīnlǐxué shìyě xià de jiědú” 中国人的 “缘” : 一种文化心理学视野下的解读 [Chinese People's “Yuan”: An Interpretation From the Point of View of Cultural Psychology]. In Ānqing shīfàn xuéyuàn xuébào 安庆师范学院学 报 [Journal of Ānqìng Teachers College], 24/6, 2005, pp. 56-59

Kim, Uichol, Kuo-Shu Yang, and Kwang-Kuo Hwang. "Contributions to Indigenous and Cultural Psychology: Understanding People in Context." In Indigenous and Cultural Psychology: Understanding People in Context, Springer, 2006, pp. 3-25

Kipnis, Andrew B. Governing Educational Desire: Culture, Politics, and Schooling in China. Chicago: The University of Chicago Press, 2011

Kray, Laura J. et al. "From What Might Have Been to What Must Have Been: Counterfactual Thinking Creates Meaning." In Journal of Personality and Social Psychology, 98/1, 2010, pp. 106-118 
Lǐ, Pèiliáng 李沛良. “Zhōngguó wénhuà de sùmìng zhǔyì yǔ néngdòng qǔxiàng” 中国文化的宿 命主义与能动取向 [Fatalism and Voluntarism in Chinese Culture]. In Zhōngguórén de guānniàn yǔ xíngwéi 中国人的观念与行为 [Concepts and Behaviour of Chinese People], edited by Qiáo Jiàn 乔健 and Pān Năigǔ 潘乃谷. Tiānjīn: Tiānjīn rénmín chūbănshè 天津人民出版社, 1995, pp. 240-252

Lǔ, Xīnmín 李新民 and Chén Mìtáo 陈密桃. "Shíyòng zhìnéng, yuánfèn xìnniàn yǔ xīnlǐ jiànkāng, gōngzuò biăoxiàn zhī xiāngguān: yǐ yòu'ěr jiàoshī wéilì” 实用智能, 缘分信念与心理健康, 工作表现之相关：以幼儿教师为例 [Correlations Between Practical Intelligence, YuanfenBeliefs, Mental Health and Job Performance: A Study Among Taiwanese Preschool Teachers]. In Zhōnghuá xīnlǐxué kān 中华心理学刊 [Chinese Journal of Psychology], 48/2, 2006, pp. 183-202

Ľ̌, Xīnmín 李新民 and Chén Mìtáo 陈密桃. “Táiwān dìqū guóxiăo jiàoshī de shíyòng zhìnéng, yuánfèn xìnniàn, nèi tuántǐ piānsī yǔ xīnlî jiànkāng, gōngzuò biăoxiàn zhī qiánzài guānlián” 台 湾地区国小教师的实用智能, 缘分信念, 内团体偏私与心理健康, 工作表现之潜在关联 [The Potential Correlation Between Taiwanese Elementary School Teachers' Practical Intelligence, Yuanfen-Beliefs, In-Group Favouritism, Mental Health and Job Performance]. In Jiàoyùxué kān 教育学刊 [Journal of Education], 29, 2007, pp. 37-72

Liu, Eric Y. and F. Carson Mencken. "Fatalistic Voluntarism and Life Happiness in Post-Socialist China." In Sociological Spectrum, 30/3, 2010, pp. 270-288

Liú, Wéitíng 刘维婷. “Dàxué xīnshēng xīnlǐ jiànkāng zhuàngkuàng fēnxī jí duìcè” 大学新生心理 健康状况分析及对策 [Analysis of Chinese Students' Mental Health Situation and Discussion of Countermeasures]. In Húběi hánshòu dàxué xuébào 湖北函授大学学报 [Journal of Húběi Correspondence University], 22/4, 2009, pp. 47-48

Liú, Wéitíng 刘维婷. “Dàxuéshēng yuánfèn guānniàn de zhìhuà yánjiū” 大学生缘分观念的质化 研究 [Qualitative Research on Chinese Students' Conception of Yuanfen]. M.A. Thesis, Hénán dàxué 河南大学 [Hénán University], 2010

Liú Wéitíng 刘维婷 and Yáng Méi 杨梅. “Zhōngguó běntǔ xīnlǐxué de kùnjìng jí chūlù” 中国本 土心理学的困境及出路 [The Difficult Situation and Solutions Concerning the Sinicisation of Psychology]. In Fùyáng shīfàn xuéyuàn xuébào 阜阳师范学院学报 [Journal of Fùyáng Teachers College], 6, 2008, pp. 108-109

Luó, Zhúfēng 罗竹风. “Yuán” 缘. In Hànyǔ dà cídiăn 汉语大词典 [The Big Dictionary of Chinese], 9. First Edition. Shànghăi 上海: Hànyǔ dà cídiăn chūbănshè 汉语大词典出版社, 1992, pp. 956-957

Mayring, Philipp. Qualitative Inhaltsanalyse: Grundlagen und Techniken. Eleventh Edition, Weinheim: Beltz, 2010

Meuser, Michael and Ulrike Nagel. "ExpertInneninterviews - vielfach erprobt, wenig bedacht: Ein Beitrag zur qualitativen Methodendiskussion.” In Qualitativ-Empirische Sozialforschung: Konzepte, Methoden, Analysen, edited by Detlef Garz and Klaus Kraimer. Opladen: Westdeutscher Verlag, 1991, pp. 441-471

Meyer, Wulf-Uwe. Einige grundlegende Annahmen und Konzepte der Attributionstheorie. Bielefeld: Universität Bielefeld, 2003

Norenzayan, Ara and Albert Lee. "It Was Meant to Happen: Explaining Cultural Variations in Fate Attributions." In Journal of Personality and Social Psychology, 98/5, 2010, pp. 702-20

Pepitone, Albert and Luisa Saffiotti. "The Selectivity of Nonmaterial Beliefs in Interpreting Life Events.” In European Journal of Social Psychology, 27, 1997, pp. 23-35 
Qí, Xiāngfēn 齐香芬. “Chuántǒng wénhuà duì xīnlǐxué zhōngguóhuà y̌̌ngxiăng chūtàn” 传统文 化对心理学中国化影响初探 [A First Discussion of the Influene of Traditional Chinese Culture on the Sinicisation of Psychology]. In Zuòjiā zázhi 作家杂志 [Writer Magazine], 10, 2011, pp. 159-60

Qū, Zhènhuī 屈振辉 and Lǐ Péichāo 李培超. “Dàxué zhāoshēng tǐzhì găigé zhōng de jiàzhí bó'yì” 大学招生体制改革中的价值博弯 [A Study of Value-Conflicts in the Reform of China's Higher Education Admission System]. In Húnán shīfàn dàxué jiàoyù kēxué xuébào 湖南师范 大学教育科学学报 [Journal of Educational Science of Hunan Normal University], 9/5, 2010, pp. $87-89$

Raphals, Lisa. "Fate, Fortune, Chance, and Luck in Chinese and Greek: A Comparative Semantic History." In Philosophy East and West, 53/4, 2003, pp. 537-574

Soothill, William Edward and Lewis Hodous. The Dictionary of Chinese Buddhist Terms. London: Kegan Paul, Trench, Trubner \& Co., 1968

Trow, Martin. Problems in the Transition from Elite to Mass Higher Education. Berkeley: Carnegie Commission on Higher Education, 1973

UNESCO Institute for Statistics. "Education (All Levels) Profile - China." 2014, Country Profiles website, http://stats.uis.unesco.org/unesco/TableViewer/document.aspx?ReportId=121\&IF_ Language $=$ eng\&BR_Country $=1560 \& B R \_$Region=40515, accessed May 2014

Wáng, Xiăoyàn 王晓燕, Liú Jiàn 刘健, and Gāo Ruì 高瑞. “Zhōngguó gāoděng jiàoyù kuò zhāo yǔ jīngjì zhènxīng” 中国高等教育扩招与经济振兴 [China’s Higher Education Expansion and the Task of Economic Revitalisation]. In Dàxué jiàoyù kēxué 大学教育科学 [University Education Science], 2, 2012, pp. 81-89

Weiner, Bernard et al. Perceiving the Causes of Success and Failure. Morristown: General Learning Press, 1971

Weiner, Bernard. “An Attributional Theory of Achievement Motivation and Emotion.” In Psychological Review, 92/4, 1985, pp. 548-573

Wenninger, Gerd. "Kultur." In Lexikon Der Psychologie, CD edition 5, Hessisch Lichtenau: EDVVerlag Saage, 2002a

Wenninger, Gerd. "Kulturstandards.” In Lexikon Der Psychologie, CD edition 5, Hessisch Lichtenau: EDV-Verlag Saage, 2002b

Wenninger, Gerd. "Schicksal.” In Lexikon Der Psychologie, CD edition 5, Hessisch Lichtenau: EDV-Verlag Saage, 2002c

Yan, Yunxiang. "The Chinese Path to Individualization.” In British Journal of Sociology, 61/3, 2010a, pp. 489-512

Yan, Yunxiang. "Introduction: Conflicting Images of the Individual and Contested Process of Individualization." In iChina: The Rise of the Individual in Modern Chinese Society, edited by Mette Halskov Hansen and Rune Svarverud. Copenhagen: Nordic Institute of Asian Studies (NIAS), 2010b, pp. 1-38

Yang, Cunzhen and Trevor Gale. "Policy Analysis: On Chinese Higher Education Entry Policy." In AARE 2004 Conference Papers, Melbourne, 2005

Yáng, Kuó-shū 杨国枢. “Xīnlǐxué yánjiū de zhōngguóhuà: céngcì yǔ fāngxiàng” 心理学研究的 中国化: 层次与方向 [The Sinicisation of Psychological Research: Stages and Directions]. In Shèhui jí xíngwéi kēxué yánjiū de zhōngguóhuà 社会及行为科学研究的中国化 [The Sinicisation of Research in Social and Behavioural Sciences], edited by Yáng Kuó-shū 杨国枢 and Wén Chóngyī 文崇一. Táiběi 台北: Zhōngyāng yánjiūyuàn mínzúxué yánjiūsuǒ 中央研究院 民族学研究所, 1982a, pp. 153-187 
Yáng, Kuó-shū 杨国枢. “Yuán jí qí zài xiàndài shēnghuó zhōng de zuòyòng” 緣及其在现代生活 中的作用 [Yuan and Its Functions in Modern Life]. In Chuántǒng wénhuà yǔ xiàndài shēnghuó yántăohuì lùnwén jí 传统文化与现代生活研讨会论文集 [Collection of Publications from the Conference on Traditional Culture and Modern Life]. Táiběi 台北: Zhōnghuá wénhuà fùxīng yùndòng tuīxíng wěiyuánhuì 中华文化复兴运动推行委员会, 1982b [1988], pp. 105128

Yáng, Kuó-shū 杨国枢. “Zhōngguórén zhī yuán de guānniàn yǔ gōngnéng” 中国人之缘的观念与 功能 [Conception and Functions of the Chinese Concept of Yuan]. In Zhōngguórén de xīnlǐ 中 国人的心理 [The Chinese Psyche]. Táiběi 台北: Guìguān túshū gōngsī 桂冠图书公司, 1988, pp. 123-154

Yang, Kuo-Shu and David Y. F. Ho. "The Role of Yuan in Chinese Social Life: A Conceptual and Empirical Analysis." In Asian Contributions to Psychology, edited by A. C. Paranjpe, David Y. F. Ho, and Robert W. Rieber. New York: Praeger, 1988, pp. 263-281

Yao, Shujie, Bin Wu, Fang Su, and Jianling Wang. "The Impact of Higher Education Expansion on Social Justice in China: a Spatial and Inter-temporal Analysis." In Journal of Contemporary China, 19/67, 2010, pp. 837-854

Zhāng, Héshēng 张和生 and Yú Jūnmín 余军民. “Gāokăo gōngpíng wèntí de shèhuì guīyīn tànxī jí duìcè yánjiū” 高考公平问题的社会归因探析及对策研究 [Analysis of Social Factors Behind the Inequality of China's National College Entrance Examination and Research of Countermeasures]. In Jiàoyù cèliàng yǔ píngjià (lùlùn băn) 教育测量与评价 (理论版) [Educational Measurement and Evaluation (Theory Edition)], 12, 2010, pp. 42-54

Zhāng, Sījiā 张思嘉 and Zhōu Yùhuì 周玉慧. “Yuán yǔ hūnqián guānxi de fāzhăn” 缘与婚前关 系的发展 [Yuan and the Development of Premarital Relationships]. In Běntǔ xīnlǐxué yánjiū 本土心理学研究 [Indigenous Psychological Research in Chinese Societies], 21, 2004, pp. 85123

Zhu, Hong and Shiyan Lou. Development and Reform of Higher Education in China. Oxford: Chandos Publishing, 2011 


\section{APPENDIX: INTERVIEWS}

\begin{tabular}{|c|c|c|c|c|c|c|c|c|}
\hline No. & sample & date & $\mathbf{m} / \mathbf{f}$ & age & $\begin{array}{c}\text { degree } \\
\text { programme }\end{array}$ & field of study & province & $\begin{array}{l}\text { hùkǒu } \\
\text { 户口 }\end{array}$ \\
\hline 1 & regular & $2012-08-26$ & $\mathrm{f}$ & 24 & M.A. 3rd year & higher education & Jiangxi & rural \\
\hline 2 & regular & 2012-08-30 & $\mathrm{f}$ & 24 & M.A. 3rd year & preschool education & Hunan & urban \\
\hline 3 & regular & 2012-09-02 & $\mathrm{m}$ & 24 & M.A. 2nd year & neuroscience & Liaoning & rural \\
\hline 4 & regular & 2012-09-02 & $\mathrm{m}$ & 22 & B.A. 4th year & physics & Gansu & rural \\
\hline 5 & regular & 2012-09-03 & $\mathrm{m}$ & 24 & M.A. 2nd year & $\begin{array}{l}\text { communications and } \\
\text { information systems }\end{array}$ & Henan & rural \\
\hline 6 & regular & 2012-09-04 & $\mathrm{f}$ & 21 & B.A. 3rd year & $\begin{array}{l}\text { teaching Chinese as a } \\
\text { foreign language }\end{array}$ & Jiangxi & urban \\
\hline 7 & $\begin{array}{l}\text { control } \\
\text { gr. }\end{array}$ & 2012-09-05 & $\mathrm{f}$ & 22 & B.A. 4th year & musical education & Shandong & urban \\
\hline 8 & regular & 2012-09-05 & $\mathrm{m}$ & 20 & B.A. 2nd year & special education & Sichuan & rural \\
\hline 9 & $\begin{array}{l}\text { control } \\
\text { gr. }\end{array}$ & 2012-09-06 & $\mathrm{m}$ & 23 & M.A. 3rd year & international relations & Shandong & urban \\
\hline 10 & $\begin{array}{l}\text { control } \\
\text { gr. }\end{array}$ & 2012-09-06 & $\mathrm{m}$ & 21 & B.A. 3rd year & psychology & Hainan & urban \\
\hline 11 & regular & 2012-09-08 & $\mathrm{m}$ & 22 & M.A. 1st year & organic chemistry & Jiangxi & urban \\
\hline 12 & $\begin{array}{l}\text { control } \\
\text { gr. }\end{array}$ & 2012-09-09 & $\mathrm{f}$ & 22 & M.A. 2nd year & $\begin{array}{l}\text { history of Chinese } \\
\text { education }\end{array}$ & Henan & rural \\
\hline 13 & regular & 2012-09-10 & f & 22 & B.A. 4th year & psychology & Henan & urban \\
\hline 14 & $\begin{array}{l}\text { control } \\
\text { gr. }\end{array}$ & 2012-09-11 & $\mathrm{m}$ & 21 & B.A. 3rd year & $\begin{array}{l}\text { finance and law } \\
\text { (double degree) }\end{array}$ & Jiangxi & rural \\
\hline 15 & regular & 2012-09-11 & $\mathrm{f}$ & 20 & B.A. 3rd year & $\begin{array}{l}\text { teaching Chinese as a } \\
\text { foreign language }\end{array}$ & Anhui & urban \\
\hline 16 & regular & 2012-09-12 & f & 23 & M.A. 1st year & special education & Shandong & rural \\
\hline 17 & regular & 2012-09-15 & $\mathrm{m}$ & 19 & B.A. 1st year & logopedics & Anhui & urban \\
\hline
\end{tabular}


Isabel Heger: The Meaning and Functions of the Concept of Yuanfen 缘分 in Contemporary China:

\begin{tabular}{|c|c|c|c|c|c|c|c|c|}
\hline 18 & regular & 2012-09-16 & $\mathrm{f}$ & 19 & B.A. 1st year & educational psychology & Shandong & rural \\
\hline 19 & regular & 2012-09-17 & $\mathrm{f}$ & 20 & B.A. 2nd year & graphic design & Shanghai & urban \\
\hline
\end{tabular}

All interviews were conducted on the campus of East China Normal University. 


\section{GLOSSARY}

$\begin{array}{ll}\text { bèi tiáojì } & \text { 被调剂 } \\ \text { dìngfèn } & \text { 定分 } \\ \text { fèn } & \text { 分 }\end{array}$

gāokăo 高考

guānxi 关系

hùkǒu

Huádōng Shīfàn Dàxué 华东师范大学

jīji

jì lái $z h \bar{l}, z e ́$ 'ān $z h \bar{l}$

nièyuán

ǒurán

ǒurán zhōng de bìrán

sān fền tiān zhùdìng, qù fên kào dăpīn

shi'èr yīnyuán

shǒu zhū dài tù

shùn qi zìrán

sùmìng néngdòng guān yin

yīnyuán

yǒu yuán wú fèn

yuán

yuàn

yuán běn tiān chéng, fèn zài rén wéi

\section{积极}

等缘

偶然

偶然中的必然

十二因缘

守株待兔

\section{顺其自然}

宿命能动观

因

因缘

有缘无分

缘
Being allocated to a field of study not even listed in one's preferences

Predestination

1) Originally added to yuán to underline the fatalistic nature of the encounter: Predestination

2) New semantic meaning: Outcome of the relationship

National college entry exam

Interpersonal relationships with personal or professional benefits for the individual household registration (rural or urban) East China Normal University (ECNU)

既来之, 则安之

三分天注定，七分靠打拼

Positive and active

To accept things as they are and make the best of it

Evil yuán

By chance, random

A necessity within the contingency of things

$30 \%$ are destined by heaven, $70 \%$ are achieved through personal struggle

Twelve Nidanas (Buddhist doctrine)

To guard a tree-stump, waiting for rabbits (lit.); to idly wait for an opportunity to fall into one's lap To follow the course of nature; to let nature take its course

Fatalistic voluntarism

In the Buddhist doctrine of the Twelve Nidanas: Primary cause

Foundation or basis; Used to translate the Buddhist doctrine of the Twelve Nidanas

There is yuán, but no fèn

1) Edge or border

2) In the Buddhist doctrine of the Twelve Nidanas: Secondary or circumstantial cause

3) See Yuánfèn: Chance by which people are brought together Seam or embroidered hem in clothing yuán comes from heaven, fèn is manmade 
yuánfèn 缘分

yuán lái suí yuàn, yuàn yǒ y yaan
Yuanfen: Subjectively perceived chance that brings people or people and events together

缘来随愿，愿有缘 yuán comes following a wish, only based on a wish will there be yuán 